\title{
Prediction of sepsis-related outcomes in neonates through systematic genotyping of polymorphisms in genes for innate immunity and inflammation: a narrative review and critical perspective
}

Previsão de desfechos relacionados a sepse em neonatos através da genotipagem sistemática de polimorfismos de genes da imunidade inata e inflamação: uma revisão narrativa e perspectiva crítica

Juliana Kilesse Carvalho', Daniella Batalha Moore", Ricardo Alves Luz'"', Pedro Paulo Xavier-Elsas'v, Maria Ignez Capella Gaspar-Elsas ${ }^{\vee}$

Instituto Fernandes Figueira (IFF), Fundação Oswaldo Cruz (Fiocruz), Rio de Janeiro, Brazil

'MD, MSc. Neonatologist, Laboratory of Human Pathophysiology, Department of Pediatrics, Instituto Fernandes Figueira (IFF), Fundação Oswaldo Cruz (Fiocruz), Rio de Janeiro, Brazil. "MD, MSc, PhD. Associate Professor, Discipline of Clinical Immunology, Department of Internal Medicine, Universidade Federal Fluminense (UFF), Niterói, Brazil.

'"MSc, PhD. Research associate, Department of Immunology, Instituto de Microbiologia Paulo de Góes (IMPG), Universidade Federal do Rio de Janeiro (UFRJ), Rio de Janeiro, Brazil.

"MD, MSc, PhD. Associate Professor, Department of Immunology, Instituto de Microbiologia Paulo de Góes (IMPG), Universidade Federal do Rio de Janeiro (UFRJ), Rio de Janeiro, Brazil.

${ }^{\vee} M D$, PhD. Head of the Laboratory of Human Pathophysiology, Department of Pediatrics, Instituto Fernandes Figueira (IFF), Fundação Oswaldo Cruz (Fiocruz), Rio de Janeiro, Brazil.

\section{KEY WORDS:}

Neonatology.

Sepsis.

Cytokines.

Genetic predisposition to disease.

Polymorphism, genetic.

\section{PALAVRAS-CHAVE:}

Neonatologia.

Sepse.

Citocinas.

Predisposição genética para doença.

Polimorfismo genético.

\begin{abstract}
CONTEXT AND OBJECTIVE: Neonatal sepsis is associated with premature birth and maternal infection. Large-scale studies seek to define markers that identify neonates at risk of developing sepsis. Here, we examine whether the scientific evidence supports systematic use of polymorphism genotyping in cytokine and innate immunity genes, to identify neonates at increased risk of sepsis.

DESIGN AND SETTING: Narrative literature review conducted at Fernandes Figueira Institute, Brazil. METHODS: The literature was searched in PubMed, Embase (Excerpta Medica Database), Lilacs (Literatura Latino-Americana e do Caribe em Ciências da Saúde), SciELO (Scientific Electronic Library Online) and Cochrane Library. From > 400,000 references, 548 were retrieved based on inclusion/exclusion criteria; 22 were selected for detailed analysis after quality assessment.

RESULTS: The studies retrieved addressed the impact of gene polymorphisms relating to immune mechanisms (most often TNF-a, LT-a, IL-6, IL-1 $\beta$, IL-1ra, L-selectin, CD14 and MBL) or inflammatory mechanisms (ACE and angiotensin II receptors; secretory PLA2; and hemostatic factors). Despite initial reports suggesting positive associations between specific polymorphisms and increased risk of sepsis, the accumulated evidence has not confirmed that any of them have predictive power to justify systematic genotyping. CONCLUSIONS: Sepsis prediction through systematic genotyping needs to be reevaluated, based on studies that demonstrate the functional impact of gene polymorphisms and epidemiological differences among ethnically distinct populations.
\end{abstract}

\section{RESUMO}

CONTEXTO E OBJETIVO: A sepse neonatal está associada ao parto prematuro e à infecção materna. Estudos em grande escala buscam marcadores que identifiquem neonatos em risco de desenvolver sepse. Examinamos aqui se a evidência científica apoia o uso sistemático de genotipagem dos polimorfismos em genes de citocinas e imunidade inata, para identificar neonatos com risco elevado de sepse.

TIPO DE ESTUDO E LOCAL: Revisão narrativa da literatura, Instituto Fernandes Figueira, Brasil. MÉTODOS: Busca online da literatura foi feita no PubMed, Embase (Excerpta Medica Database), Lilacs (Literatura Latino-Americana e do Caribe em Ciências da Saúde), SciELO (Scientific Electronic Library Online) e Cochrane Library. De mais de 400.000 referências, 548 foram recuperadas com base nos critérios de inclusão/exclusão, e 22, selecionadas para análise detalhada após verificação da qualidade.

RESULTADOS: Recuperamos estudos de impacto dos polimorfismos em genes relacionados com mecanismos imunes (mais frequentemente, TNF-a, LT-a, IL-6, IL-1ß, IL-1 ra, L-selectin, CD14, e MBL) ou inflamatórios (ACE e receptores de angiotensina II; PLA2 secretória; fatores hemostáticos). Contrariando estudos que inicialmente sugeriram associação positiva entre polimorfismos específicos e risco aumentado de sepse, a evidência acumulada não confirmou, para qualquer deles, valor preditivo que justifique genotipagem sistemática para orientar antibioticoterapia.

CONCLUSÕES: A previsão da sepse por meio de genotipagem sistemática precisa ser reavaliada, com base em estudos que demonstram o impacto funcional de polimorfismos gênicos e as diferenças epidemiológicas entre populações etnicamente distintas. 


\section{INTRODUCTION}

Neonatal sepsis, defined by systemic circulatory abnormalities (predominantly peripheral vasoconstriction, oliguria and ischemic damage to inner organs) and a variable spectrum of clinical signs, resulting from invasion of the bloodstream by bacteria and other pathogens, as well as from the ineffective host response, in infants up to their first month of life. ${ }^{1}$

It results in one million deaths each year $(42 \%$ in the first week of life). This amounts to $10 \%$ of all mortality under the age of five years. ${ }^{2}$ In Brazil, neonatal sepsis is a leading cause of mortality during the neonatal period, which represents an estimated $60 \%$ of all childhood mortality. ${ }^{3}$

Many of the clinical problems in recognition and management of neonatal sepsis are related to the complex biology of the neonatal period, when the physiological immaturity of the immune system and the fragility of the skin and mucosal barriers can be accompanied by a variety of additional risk factors. Neonatal sepsis is defined by: a) differential exposure to specific classes of infectious pathogens; b) the additional impacts of prematurity, low birth weight (LBW) and very low birth weight (VLBW); c) exposure to use of immunomodulatory drugs; and d) risks associated with therapeutic procedures in neonatal intensive care units. ${ }^{4-9}$

Diversity of infectious exposures is relevant to the clinical differences between early-onset and late-onset neonatal sepsis. The former is classically associated with pathogens present at the fetal-maternal interface, ${ }^{10}$ while the latter (much more frequent) reflects invasion from nosocomial microorganisms, with a risk that increases with the length of hospitalization and invasiveness of procedures, and when microbiological control is suboptimal., ${ }^{911,12}$ The risks of neonatal infection and sepsis are inversely proportional to gestational age, thus suggesting that critical components of the immune system reach maturity only in the final weeks of gestation, ${ }^{13,14}$ just before the newborn needs them to successfully manage the transition from microbiological sterility to colonization by a healthy microbiota. It remains to be established whether the increase in birth weight as gestational age approaches 37 weeks of gestation plays any additional role in protecting the neonate from infection. ${ }^{14}$

The variable of clinical evolution of neonatal sepsis is related to individual variability in immune competence, especially with regard to innate immunity, ${ }^{15}$ and to differences in responses to therapy. It is difficult to define which infants are at greatest risk of developing sepsis, among those exposed to similar environmental challenges. Even after sepsis has already developed, it remains difficult to monitor it through specific laboratory criteria, since pathogen isolation from blood and other sites is limited by low sensitivity and by the limited amounts that can be sampled. Aggressive antibiotic prophylaxis, on the other hand, significantly increases the risk of drug toxicity in premature infants, who lack efficient renal and hepatic detoxification mechanisms. Consequently, there is still a lack of tests for ensuring early and reliable diagnosing of neonatal sepsis, and for defining the patients who are most likely to benefit from aggressive antimicrobial treatment. ${ }^{16,17}$

A comprehensive review by Härtel et al. ${ }^{18}$ addressed the complexities involved in defining the individual differences that influence the risk of neonatal sepsis and related outcomes, especially with regard to specific genes of relevance to the host-pathogen relationship and to the collective influence of gene pools that differ among ethnically diverse populations. These authors acknowledged that host genetic markers with prognostic value for sepsis might be helpful in managing the neonates who would be most likely to benefit from aggressive antimicrobial therapy, and they put the challenges involved into perspective. In addition to the technical difficulties inherent to all genotyping studies, the diversity of candidate genes, multiplicity of existing alleles at each locus and variable locations of polymorphisms in promoter regions, exons and introns, as well as their highly unpredictable functional impact, must be taken into account. By definition, no single locus is thought to control susceptibility to neonatal sepsis, but a number of candidate genes have been studied because their biological effects that have been demonstrated or predicted would be consistent with a plausible pathogenetic mechanism.

This is the case of genes expressed in the context of innate immunity and inflammation, including: a) cytokines and related regulatory factors (TNF-a, LT-a, IL-6, IL-1 $\beta$ and IL-1ra); b) microbial recognition receptors (CD14, toll-like receptors and nucleotide-binding oligomerization domains/NOD); c) microbicidal proteins (mannose-binding lectin/MBL); and d) systemic effectors of inflammation in general (secretory phospholipase A2/PLA2, angiotensin/AT-converting enzyme/ACE and ATII receptors, and factors involved in hemostasis).

The review by Härtel et al. emphasized the need for: a) reproduction of the initial results in larger cohorts; b) adherence to rigorous definitions of sepsis and related outcomes; and c) adequate control over the effects of ethnic variation. ${ }^{18}$ However, these authors did not issue specific recommendations for systematic screenings for any of the above genes in the context of neonatal sepsis. Because of the significant number of studies published since their original review of this field, we have reassessed here whether the available evidence warrants such recommendations.

\section{OBJECTIVE}

This study aimed to analyze whether the available scientific evidence supports systematic use of genotyping of one or more polymorphisms in cytokine and innate immunity genes as a means of identifying neonates who are at increased risk of sepsis. 


\section{METHODS}

We conducted an online review of the literature, and followed the guidelines provided by Preferred Reporting Items for Systematic reviews and Meta-Analyses (PRISMA). We searched the scientific literature for published studies that support use of genotyping for single nucleotide polymorphisms (SNPs) in newborns as biomarkers associated with the risk of sepsis and/or its complications. The selection of studies for detailed analysis was carried out independently by two investigators, who had received training in Allergy and Clinical Immunology and had professional experience in Neonatology. The steps in retrieval and analysis of the literature were as follows:

\section{Identification of primary studies}

We carried out a systematic search of electronic databases for published studies, primarily in PubMed Medline, but also including SciELO (Scientific Electronic Library Online), Embase (Excerpta Medica Database) and, through the Virtual Health Library (BVS), the Lilacs (Literatura Latino-Americana e do Caribe em Ciências da Saúde) and Cochrane Library databases. We did not search other databases that include unpublished studies, dissertations and theses, or research projects. The search of the literature was based on the PICO strategy, which is an acronym for the following: $\mathrm{P}$ (patient) - newborns aged 0-28 months, without restriction on studies between term and preterm, or between LBW and VLBW; I (intervention) - the studies included conducted genotyping of polymorphisms in order to evaluate associations with the risk of neonatal sepsis; C (comparison) comparison between groups with and without neonatal sepsis, correlating with the genetic polymorphisms found; and $\mathrm{O}$ (outcome) - neonatal sepsis.

The following Medical Subject Headings (MeSH) subheadings were used: "neonate or premature or VLBW or LBW"; "sepsis or neonatal infections"; "polymorphism or polymorphisms or genetic variability or polymorphism or genotype". The search strategy is summarized in Table 1.

Our latest search was finished in September 2012. References in English, Spanish and Portuguese were analyzed, while articles in other languages for which only the abstract could be obtained in English were excluded.

\section{Study selection for analysis}

Case-control studies evaluating the impact of genetic variability on sepsis in newborns were included. The patient group was composed of septic newborns and the control group was composed of healthy newborns or non-septic newborns. The relevant outcome was neonatal sepsis.

We excluded the following: case reports; studies that did not evaluate sepsis as an outcome; methodological reviews and technical studies; studies focusing on children outside of the neonatal age group; studies on genetic diversity of pathogens rather than on patients; and any other papers retrieved that did not match the inclusion criteria.

The abstracts of all studies identified in the original search after combining the descriptors were evaluated. After elimination of all papers that failed to meet the inclusion criteria, the manuscripts were fully analyzed.

All the papers that were subjected to in-depth analysis had been retrieved through the primary PubMed search, even though some of them were also retrieved through the complementary searches in Embase, Lilacs, SciELO and the Cochrane Library.

\section{Quality assessment}

Three of the co-authors (Moore DB, Gaspar-Elsas MI and Carvalho JK) independently applied the previously published methodological standards of Bogardus et al. ${ }^{19}$ for assessing the quality of molecular genetic studies within the field of clinical epidemiology, following the recommendations of Peters et al. ${ }^{20}$ A total of 22 papers were evaluated with regard to the following methodological standards: reproducibility, objectivity, case definition, adequacy of case group spectrum, control group definition, adequacy of the control group and quantitative summary (Table 2). ${ }^{921-41}$ We further assessed the quality of the studies by means of the checklist of Downs and Black (Table 3). ${ }^{42}$ Exclusions were always based on noncompliance with the criteria of the ideal methodological standard. In addition, every study was further examined for possible methodological flaws and interpretation of findings. ${ }^{43}$

\section{Data analysis}

In this step, we aimed to define whether the conclusions in each paper did or did not support the assumption that genotyping of polymorphisms of interest is well-established as a laboratory test for systematic evaluation of the risk of neonatal sepsis and its complications. Data from each of the selected references that were used for this definition were summarized in a descriptive form, excluding technical details and quantitative data, but recording the nature of the evidence, clarity of the measurements, adequacy of the methods, information on potential conflicts of interest and coherence between the actual data and the conclusions and/or recommendations.

\section{RESULTS}

A total of 548 papers were analyzed on the basis of their titles and abstracts, and the following were excluded: 20 technical protocols; 6 reviews; 231 papers that addressed genetic diversity of pathogens, rather than genetic diversity of patients; 198 papers that did not study sepsis as a relevant outcome; 59 studies 
that comprised age groups other than only neonates; 7 studies that did not address genetic polymorphisms; 2 case reports; 1 study that did not evaluate humans; 1 paper written in Polish, with no English translation; and 1 study that was not available. The remaining 22 articles were fully analyzed ${ }^{9,21-41}$ (Table 4). Their contents were summarized in the following sections, which address different SNPs. In several studies addressing more than one specific polymorphism, the information on each polymorphism is summarized with emphasis proportional to the degree of statistical and epidemiological relevance, as well as to the attention it received in previous studies.

\section{TNF-alpha gene polymorphism}

We retrieved four studies addressing the association between the SNP TNF-308 and development of neonatal sepsis. A study carried out on a small cohort of 103 neonates did not show any association between the SNP TNF-308 and neonatal sepsis. ${ }^{41}$ Similar negative results were found in two additional studies. The first included 173 VLBW neonates who underwent mechanical ventilation, ${ }^{37}$ while the other ${ }^{31}$ compared the frequency of this genotype among 61 premature neonates ( $<32$ weeks) with early-onset sepsis and among 102 healthy neonates ( $>32$ weeks). However, in the first study by Hedberg

Table 1. Search strategy

\begin{tabular}{|c|c|c|c|c|}
\hline Electronic search & Database & Filters & Search terms & Results \\
\hline $\begin{array}{l}\text { Search through NCBI (http://www. } \\
\text { ncbi.nlm.nih.gov/pubmed) }\end{array}$ & PubMed & $\begin{array}{l}\text { Limits: human, newborn, } \\
\text { case control studies }\end{array}$ & \multirow{3}{*}{$\begin{array}{c}\text { (neonate OR premature OR } \\
\text { VLBW OR LBW) AND } \\
\text { (sepsis OR neonatal infections) } \\
\text { AND } \\
\text { (polymorphism OR } \\
\text { polymorphisms OR genetic } \\
\text { variability OR genotype) }\end{array}$} & \multirow{3}{*}{ 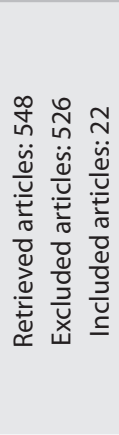 } \\
\hline $\begin{array}{l}\text { Search through Bireme-BVS } \\
\text { (http://regional.bvsalud.org) }\end{array}$ & $\begin{array}{l}\text { Lilacs (Literatura Latino- } \\
\text { Americana e do Caribe em } \\
\text { Ciências da Saúde) } \\
\text { Cochrane Library }\end{array}$ & $\begin{array}{l}\text { Limits: human, newborn } \\
\text { Major subject: genetic } \\
\text { polymorphism } \\
\text { No limits }\end{array}$ & & \\
\hline $\begin{array}{l}\text { Search though SciELO } \\
\text { (http://www.scielo.org) }\end{array}$ & $\begin{array}{c}\text { SciELO (Scientific Electronic } \\
\text { Library Online) }\end{array}$ & No limits & & \\
\hline
\end{tabular}

VLBW = very low birth weight; $L B W=$ low birth weight.

Table 2. Evaluation of methodological quality using Bogardus method

\begin{tabular}{|c|c|c|c|c|c|c|c|}
\hline Study & 1 & 2 & 3 & 4 & 5 & 6 & 7 \\
\hline Aydemir et al. ${ }^{21}$ & no & yes & yes & yes & yes & no & yes \\
\hline Härtel et al. ${ }^{9}$ & no & yes & yes & yes & yes & no & yes \\
\hline Abu-Maziad et al. ${ }^{22}$ & no & yes & yes & yes & yes & no & no \\
\hline Koroglu et al. ${ }^{24}$ & no & yes & yes & yes & yes & no & yes \\
\hline Spiegler et al. ${ }^{25}$ & no & yes & yes & yes & yes & no & yes \\
\hline Reiman et al. ${ }^{28}$ & no & yes & yes & yes & yes & no & yes \\
\hline Dzwonek et al. ${ }^{29}$ & no & yes & yes & yes & yes & no & yes \\
\hline van Der Zwet et al. ${ }^{30}$ & no & yes & yes & no & no & no & yes \\
\hline Schueller et al. ${ }^{31}$ & no & yes & yes & yes & no & yes & yes \\
\hline Derzbach et al. ${ }^{32}$ & no & yes & yes & yes & yes & no & no \\
\hline Hedberg et al. ${ }^{37}$ & no & yes & yes & yes & yes & no & no \\
\hline Ahrens et al. ${ }^{38}$ & no & yes & yes & yes & yes & no & yes \\
\hline Bessler et al..$^{39}$ & no & yes & yes & yes & yes & no & yes \\
\hline Harding et al. ${ }^{40}$ & yes & yes & yes & yes & yes & yes & yes \\
\hline Treszl et al. ${ }^{41}$ & no & yes & yes & yes & yes & no & yes \\
\hline
\end{tabular}


et al., the septic patients presenting AA/GA genotypes had a mortality rate from sepsis that was three times greater than among those presenting the GG genotype. ${ }^{37}$

The remaining doubts about the lack of association between the SNP TNF-308 and development of neonatal sepsis, which had persisted mainly due to the limited sample size of the studies carried out earlier, were subsequently ruled out by a study on 2870 VLBW infants. ${ }^{9}$ This study had the following strong points, besides the large cohort size: a) genotyping supported by functional studies; b) stringent criteria for sepsis (microbiologically-proven); and c) confirmation of Hardy-Weinberg equilibrium. Its limitations were: a) no assessment of ethnicity; and b) limited microbiological information.

Thus, although being a carrier of the SNP TNF-308A was shown to increase the risk of sepsis in a meta-analysis that included mostly adults and older children, ${ }^{44}$ there is so far no evidence of any association between the SNP TNF-308 G/A and increased risk of sepsis during the neonatal period.

Table 3. Assessment of study quality by means of the Downs and Black checklist ${ }^{42}$

\begin{tabular}{|c|c|c|c|c|c|c|c|c|c|c|c|c|c|c|c|c|c|c|c|c|c|c|}
\hline 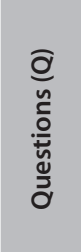 & 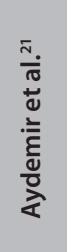 & 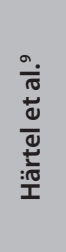 & 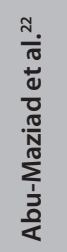 & 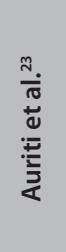 & 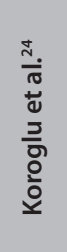 & 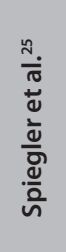 & 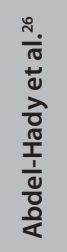 & $\begin{array}{l}\frac{\pi}{\pi} \\
\frac{\pi}{0} \\
\frac{\pi}{\pi} \\
\frac{\pi}{\pi} \\
\frac{2}{2} \\
\infty\end{array}$ & 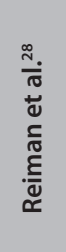 & 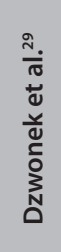 & 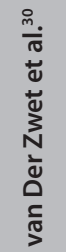 & 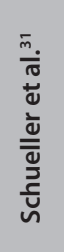 & 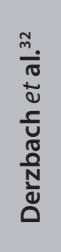 & 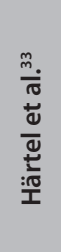 & 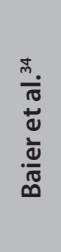 & 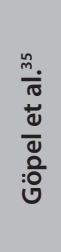 & 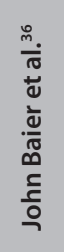 & 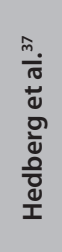 & 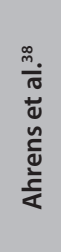 & 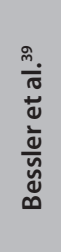 & 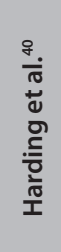 & 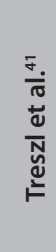 \\
\hline Q 1 & yes & yes & yes & yes & yes & yes & yes & yes & yes & yes & yes & yes & yes & yes & yes & yes & yes & yes & yes & yes & yes & yes \\
\hline Q 3 & yes & yes & yes & yes & yes & yes & yes & yes & yes & yes & yes & yes & yes & yes & yes & yes & yes & yes & yes & yes & yes & yes \\
\hline Q 4 & yes & yes & yes & yes & yes & yes & yes & yes & yes & yes & yes & yes & yes & yes & yes & yes & yes & yes & yes & yes & yes & yes \\
\hline Q 5 & yes & yes & yes & yes & yes & yes & yes & yes & yes & yes & yes & yes & yes & yes & yes & yes & yes & yes & yes & yes & yes & yes \\
\hline Q 6 & yes & yes & yes & yes & yes & yes & yes & yes & yes & yes & yes & yes & yes & yes & yes & yes & yes & yes & yes & yes & yes & yes \\
\hline Q 10 & no & yes & yes & yes & yes & yes & yes & yes & yes & yes & no & yes & yes & yes & yes & yes & yes & yes & yes & yes & yes & no \\
\hline Q 18 & yes & yes & yes & yes & yes & yes & yes & yes & yes & yes & yes & yes & yes & yes & yes & yes & yes & yes & yes & yes & yes & yes \\
\hline Q 20 & yes & yes & yes & yes & yes & yes & yes & yes & yes & yes & yes & yes & yes & yes & yes & yes & yes & yes & yes & yes & yes & yes \\
\hline Q 21 & yes & yes & yes & yes & yes & yes & yes & yes & yes & yes & yes & no & yes & yes & yes & yes & yes & yes & yes & yes & yes & yes \\
\hline Q 22 & yes & yes & yes & yes & yes & yes & yes & yes & yes & yes & yes & yes & yes & yes & yes & yes & yes & yes & yes & yes & yes & yes \\
\hline Q 25 & no & yes & yes & yes & yes & yes & yes & yes & yes & yes & yes & no & yes & yes & yes & yes & yes & yes & yes & yes & yes & yes \\
\hline Q 27 & no & yes & yes & no & yes & no & no & no & yes & no & no & no & no & yes & yes & no & no & no & yes & no & yes & no \\
\hline
\end{tabular}

Down and Black checklist for assessing study quality. Q 1 = Is the hypothesis/aim/objective of the study clearly described?; Q 2 = Are the main outcomes to be measured clearly described in the Introduction or Methods section?; Q 3 = Are the characteristics of the patients included in the study clearly described?; Q $4=$ Are the interventions of interest clearly described?; Q 5 = Are the distributions of principal confounders in each group of subjects to be compared clearly described?; Q 6 = Are the main findings of the study clearly described?; Q 7 = Does the study provide estimates of the random variability in the data for the main outcomes?; Q 8 = Have all important adverse events that may be a consequence of the intervention been reported?; Q $9=$ Have the characteristics of patients lost to follow-up been described? Q 10 = Have actual probability values been reported (e.g. 0.035 rather than < 0.05) for the main outcomes except where the probability value is less than 0.001 ?; Q 11 = Were the subjects asked to participate in the study representative of the entire population from which they were recruited?; $\mathrm{Q} 12$ = Were those subjects who were prepared to participate representative of the entire population from which they were recruited?; Q 13 = Were the staff, places, and facilities where the patients were treated, representative of the treatment the majority of patients receive?; Q $14=$ Was an attempt made to blind study subjects to the intervention they have received?; Q 15 = Was an attempt made to blind those measuring the main outcomes of the intervention?; Q 16 = If any of the results of the study were based on "data dredging", was this made clear?; Q $17=$ In trials and cohort studies, do the analyses adjust for different lengths of follow-up of patients, or in case-control studies, is the time period between the intervention and outcome the same for cases and controls?; Q 18 = Were the statistical tests used to assess the main outcomes appropriate?; Q $19=$ Was compliance with the intervention/s reliable?; Q 20 = Were the main outcome measurements used accurate (valid and reliable)?; Q 21 = Were the patients in different intervention groups (trials and cohort studies) or were the cases and controls (case-control studies) recruited from the same population?; Q 22 = Were study subjects in different intervention groups (trials and cohort studies) or were the cases and controls (case-control studies) recruited over the same period of time?; Q $23=$ Were study subjects randomized to intervention groups?; Q 24 = Was the randomized intervention assignment concealed from both patients and healthcare staff until recruitment was complete and irrevocable?; Q 25 = Was there adequate adjustment for confounding in the analyses from which the main findings were drawn?; Q $26=$ Were losses of patients from follow-up taken into account?; Q 27 = Did the study have sufficient power to detect a clinically important effect where the probability value for a difference being due to chance is less than $5 \%$ ?

Note: Questions 7, 8, 9, 12, 16, 17, 19, 23, 24 and 26 were considered to be not applicable to the type of studies included in this in-depth review. 
Table 4. Scientific literature subjected to in-depth review

\begin{tabular}{|c|c|c|c|c|}
\hline Author & Year & Country & Patients & Controls \\
\hline Aydemir et al. ${ }^{21}$ & 2011 & Turkey & $\begin{array}{l}31 \text { preterm infants with fungal } \\
\text { septicemia }\end{array}$ & $\begin{array}{l}30 \text { preterm infants who had no } \\
\text { invasive fungal infection }\end{array}$ \\
\hline Hartel et al. ${ }^{9}$ & 2011 & Germany & $\begin{array}{c}\text { Cohort 1: } 344 \text { septic VLBW } \\
\text { infants; } \\
\text { Cohort 2: } 555 \text { septic VLBW infants }\end{array}$ & $\begin{array}{c}\text { Cohort 1: } 1600 \text { non-septic } \\
\text { VLBW infants; } \\
\text { Cohort 2: } 371 \text { non-septic VLBW } \\
\text { infants }\end{array}$ \\
\hline Abu-Maziad et al. ${ }^{22}$ & 2010 & USA & 79 preterm infants with sepsis & $\begin{array}{l}202 \text { preterm infants without } \\
\text { sepsis }\end{array}$ \\
\hline Auriti et al..$^{23}$ & 2010 & Italy & 42 neonates with sepsis & 85 neonates without infection \\
\hline Koroglu et al. ${ }^{24}$ & 2010 & Turkey & $\begin{array}{l}\text { Proven sepsis: } 11 \text { preterm } \\
\text { newborns; } \\
\text { Clinical sepsis: } 42 \text { preterm } \\
\text { newborns }\end{array}$ & $\begin{array}{l}57 \text { preterm infants with no } \\
\text { sepsis }\end{array}$ \\
\hline Spiegler et al. ${ }^{25}$ & 2010 & Germany & $\begin{array}{c}706 \text { septic VLBW infants } \\
\text { genotyped for ACE-ins/del } \\
\text { genotype; } \\
709 \text { septic VLBW infants } \\
\text { genotyped for ATR-1166A/C } \\
\text { genotype }\end{array}$ & $\begin{array}{l}503 \text { non-septic VLBW infants } \\
\text { genotyped for ACE-ins/del } \\
\text { genotype;495 non-septic VLBW } \\
\text { infants genotyped for ATR- } \\
\text { 1166A/C genotype }\end{array}$ \\
\hline
\end{tabular}

$\begin{array}{lllll}\text { Abdel-Hady et al. }{ }^{26} & 2009 & \text { Egypt } & 54 \text { septic full-term neonates } & \begin{array}{c}70 \text { non-septic matched full- } \\ \text { term neonates }\end{array} \\ \text { Bertalan et al. }{ }^{27} & 2008 & \text { Hungary } & 22 \text { septic preterm neonates } & \begin{array}{c}103 \text { non-septic preterm } \\ \text { neonates }\end{array}\end{array}$

Reiman et al. $28 \quad 2008 \quad$ Finland 11 septic preterm VLBW infants

\begin{tabular}{|c|c|c|c|}
\hline Dzwonek et al. ${ }^{29}$ & 2008 & $\begin{array}{l}\text { England/ } \\
\text { Poland }\end{array}$ & 47 septic preterm infants \\
\hline van der Zwet et al. ${ }^{30}$ & 2008 & Holland & $\begin{array}{l}\text { Low MBL genotype: } 8 \text { septic } \\
\text { neonates; } \\
\text { Medium MBL genotype: } 15 \text { septic } \\
\text { neonates; } \\
\text { High MBL genotype: } 41 \text { septic } \\
\text { neonates }\end{array}$ \\
\hline Schueller et al. ${ }^{31}$ & 2006 & Germany & $\begin{array}{l}67 \text { preterm infants }(<32 \text { weeks of } \\
\text { gestation) and early-onset sepsis }\end{array}$ \\
\hline
\end{tabular}

111 non-septic preterm infants
96 non-septic preterm VLBW

Low MBL genotype: 30 nonseptic neonates;

Medium MBL genotype: 60 non-septic neonates

High MBL genotype: 44 nonseptic neonates

102 healthy newborns born after 32 weeks of gestation infants
TLR2, TLR5, IL-10 and PLA2G2A

polymorphisms predispose to sepsis in preterm infants

No association between the MBL2 genotypes and sepsis

No association between MBL polymorphism and culture-proven sepsis; however, a risk of clinical sepsis was shown

No impact of any renin-angiotensin system SNPs; no association was found between the ATR-1166A/C genotype or ACE-ins/del genotype and neonatal sepsis

The IL-6 -174 and IL-10-1082 genotypes were not significantly different in neonates with bloodstream infections, compared with controls

Bcll, N363S and ER22/23EK polymorphisms of the glucocorticoid receptor gene were not associated with risk of sepsis

Association between the IL-6-174

CC genotype and increased sepsis prevalence in VLBW infants

Analyses of the effect of MBL genotype in newborns of gestational age $<28$ weeks and birth weight $<1000 \mathrm{~g}$ did not show a statistically significant association with sepsis

No relationship was found between $M B L$ genotype and the risk of nosocomial sepsis

No association between polymorphisms of TNF-308 and LTA +252 and early-onset sepsis in newborns with $<32$ weeks of gestation.

No association was found between the polymorphisms E-selectin Ser128Arg, P-selectin Thr715Pro, L-selectin Pro213Ser and the risk of sepsis

Higher rate of sepsis for carriers of
Hartel et al. ${ }^{33}$

2006 Germany
198 septic VLBW infants
1008 non-septic VLBW infants factor XIII Val34Leu SNP

Continues... 
Table 4. Continuation

\begin{tabular}{|c|c|c|c|c|c|}
\hline Author & Year & Country & Patients & Controls & Findings \\
\hline Baier et al. ${ }^{34}$ & 2006 & Canada & 148 septic VLBW infants & 145 non-septic VLBW infants & $\begin{array}{l}\text { The IL- } 6 \text { - } 174 \text { C allele was associated } \\
\text { with increased incidence of late } \\
\text { bloodstream infection (BSI) in AA but } \\
\text { not in Caucasian infants. The IL-10 } \\
-1082 \mathrm{~A} \text { allele was associated with } \\
\text { increased incidence of late BSI. The } \\
\text { CD14 - } 260 \text { C/T SNP did not alter the } \\
\text { overall risk of BSI in ventilated } \\
\text { VLBW infants. }\end{array}$ \\
\hline Göpel et al. ${ }^{35}$ & 2006 & Germany & $\begin{array}{l}97 \text { VLBW infants who evolved } \\
\text { with sepsis }\end{array}$ & 320 non-septic VLBW infants & $\begin{array}{l}\text { No association between sepsis and } \\
\text { IL-6-174 genetic polymorphism }\end{array}$ \\
\hline John Baier et al. ${ }^{36}$ & 2005 & Canada & 149 septic VLBW infants & 146 non-septic VLBW infants & $\begin{array}{l}\text { The ACE I/D polymorphism did not } \\
\text { have a significant effect on } \\
\text { incidence of sepsis }\end{array}$ \\
\hline Ahrens et al. ${ }^{38}$ & 2004 & Germany & 50 septic VLBW infants & 306 non-septic VLBW infants & $\begin{array}{l}\text { VLBW infants carrying the } \\
\text { NOD2-3020ins C allele }(n=15) \text { and } \\
\text { the IL-6-174 G allele }(n=121) \text { had } \\
\text { a significantly higher rate of blood } \\
\text { culture-proven sepsis. }\end{array}$ \\
\hline Bessler et al. ${ }^{39}$ & 2004 & Israel & $\begin{array}{l}34 \text { septic preterm LBW infants } \\
\text { aged } 24-35 \text { weeks of gestation }\end{array}$ & $\begin{array}{l}61 \text { non-septic preterm LBW } \\
\text { infants aged } 24-35 \text { weeks of } \\
\text { gestation }\end{array}$ & $\begin{array}{l}\text { No impact of IL-1 ra genetic } \\
\text { polymorphism on early onset sepsis }\end{array}$ \\
\hline Harding et al. ${ }^{40}$ & 2003 & England & $\begin{array}{c}51 \text { septic preterm infants aged }< \\
32 \text { weeks of gestation. }\end{array}$ & $\begin{array}{l}106 \text { non-septic preterm infants } \\
\text { aged < } 32 \text { weeks of gestation. }\end{array}$ & $\begin{array}{l}\text { Increased confirmed bacteriological } \\
\text { sepsis with IL-6-174 GG allele }\end{array}$ \\
\hline Treszl et al. ${ }^{41}$ & 2003 & Hungary & 33 septic VLBW neonates & 35 non-septic VLBW neonates & $\begin{array}{l}\text { TNF-308, IL-1 } 1 \text {, IL-4 receptor } \alpha \text { chain, } \\
\text { IL- } 6 \text { and IL-10 genes are not risk factors } \\
\text { for sepsis in LBW infants }\end{array}$ \\
\hline
\end{tabular}

VLBW = very low birth weight; $L B L=$ low birth weight; $B S I=$ bloodstream infection; $M B L=$ mannose-binding lectin; TNF = tumor necrosis factor; IL-6 = interleukin 6; IL $1 \beta=$ interleukin 1 $\beta$; IL-4 = interleukin 4;TLR2 = toll-like receptor 2; TLR5 = toll-like receptor 5; ACE I/D = angiotensin converting enzyme insertion/ deletion; ATR = angiotensin II type 1 receptor; PLA2G2A = phospholipase A2, group IIA; LTA = lymphotoxin alpha; SNP = single nucleotide polymorphism.

\section{Interleukin-6 gene polymorphism}

Six studies addressing the association between the SNP IL-6-174 and neonatal sepsis were identified. Two of them showed that there was a small risk associated with the SNP IL-6-174 C allele and neonatal sepsis. The first study ${ }^{40}$ included 157 neonates (<32 weeks) predominantly composed of Caucasians (92\%) and showed that there was a risk of neonatal sepsis associated with the SNP IL-6-174 GG (odds ratio, OR = 2.7; P = 0.01; in comparison with GA/AA). The strong points of this study included: a) very stringent criteria for septicemia (which may well have contributed to the strong effect detected); b) Hardy-Weinberg equilibrium and ethnicity evaluation; and c) correction for bias of multiple siblings. The limitations were essentially due to the small cohort size. Similar results were found by Ahrens et al. ${ }^{38}$ in a study that included 356 VLBW Caucasian infants and showed that there was a risk of neonatal sepsis associated with the SNP IL-6-174 GG (OR=0.19; $\mathrm{P}=0.03)$. This study also showed that the higher rate of sepsis in this group reflected higher infection rates due to Gram-positive organisms, and that sepsis was not detected in patients who had been given prophylaxis using teicoplanin.

Apparently contradictory results were seen by Baier et al. ${ }^{34}$ in a study that included 293 VLBW infants (< 1500 g; comprising 233 African-American, 57 Caucasian and three Latin-American infants) who underwent mechanical ventilation. This study showed that the IL-6-174 C allele was associated with increased incidence of sepsis. However, this effect was observed only in African-American subjects and not in Caucasian subjects. With a small cohort of 33 septic, 35 infected and 35 healthy VLBW infants, Treszl et al. ${ }^{41}$ also failed to detect an association. Another study, with a large cohort that included 1206 VLBW preterm infants, mostly Caucasian, was equally unable to show any association between the SNP IL-6-174 and neonatal sepsis. ${ }^{35}$ The strong points in this study included: a) large cohort size; b) careful microbiological characterization of bloodstream infections and colonization; and c) stringent criteria for sepsis. Recently, data from these five studies were consolidated into a meta-analysis ${ }^{45}$ that showed 
that the SNP IL-6-174 had a modest carrier C effect in relation to neonatal sepsis (RR 0.9; 95\% CI 0.62-1.31).

After this meta-analysis, Reiman et al. ${ }^{28}$ carried out a study that included 107 VLBW infants and showed that a risk of sepsis was associated with the SNP IL-6-174 CC (CC versus (vs) GG: $\mathrm{OR}=3.05 \mathrm{P}=0.15$; CC vs GC: $\mathrm{OR}=18.27, \mathrm{P}=0.01)$. Although this Finnish study did not describe the ethnicity of the population included, the only other population for which an increased risk of sepsis was demonstrated in association with genotype CC consisted of African-Americans, ${ }^{34}$ who are probably not representative of the population studied by Reiman et al. ${ }^{28}$ It therefore remains to be seen whether ethnicity plays a role in the apparent discrepancies between the data from Reiman et al. and from other studies. In another study on an Egyptian population that included 54 fullterm neonates presenting bloodstream infections and 70 matched full-term neonates, Abdel-Hady et al. also found no association between the SNP IL-6-174 and neonatal sepsis. ${ }^{26}$

Therefore, the real association presented by the SNP IL-6174 with neonatal sepsis development remains an open question, even for a particular ethnic group, apart from AfricanAmericans. Further studies are necessary with a larger sample size. Two points should be considered in future studies. The first concerns the importance of description and, if possible, assessment of genotypic stratification according to ethnicity. The second concerns the importance of including the microbiological identification of the agent in the sepsis definition, since there is evidence that the SNP IL-6-174 may be related to an increased risk of sepsis caused by Gram-positive organisms.

\section{Mannose-binding lectin polymorphism}

Mannose-binding lectin (MBL) is a human collectin and an important protein in the humoral innate immune system. MBL is a circulating pattern-recognition molecule that recognizes carbohydrate structures on the surface of a wide range of microorganisms, including bacteria, viruses, yeasts, protozoa and multicellular parasites, and thereby provides first-line defense. It also activates the complement system through a distinctive third pathway, independent of both antibody and C1 components..$^{28,46}$

Our search retrieved five studies that addressed the impact of MBL polymorphism and neonatal sepsis, but none of them identified any association between this genetic polymorphism and neonatal sepsis. A study that included 742 neonates did not find any association between MBL2 gene polymorphism and neonatal sepsis. ${ }^{30}$ The strong points of this study were firstly its large cohort size and secondly good microbiological characterization of sepsis cases. Interestingly, the authors suggested that the possible cause of the lack of association could be a reflection of the predominance of bloodstream infections due to coagulase-negative staphylococci. MBL is not very helpful against these organisms.
Similar negative results were found in another study carried out on 158 preterm infants. ${ }^{29}$ In this study, predominance of infection by coagulase-negative staphylococci was also observed. One important finding was the demonstration that MBL level, low birth weight and low gestational age were independently associated with the risk of sepsis. The probability of sepsis in neonates of $<28$ weeks or $<1000 \mathrm{~g}$ with MBL levels $<400 \mathrm{ng} / \mathrm{ml}$ was found to be $70 \%$ in that study; in contrast, for those with MBL levels above $400 \mathrm{ng} / \mathrm{ml}$, the risk of sepsis was $47 \%$.

Auriti et al. ${ }^{23}$ also showed, in a prospective study on 365 neonates, that the median MBL concentration on admission was significantly lower in infected than in non-infected neonates $(\mathrm{P}<0.001)$. Moreover, they showed that lower levels of MBL on admission were associated with an increased risk of infection, independently of gestational age and invasive procedures. Another interesting finding in this study resulted from stratification of the neonates according to the pathogens isolated in blood cultures. Lower levels of MBL were significantly associated with a risk of sepsis due to Gram-negative organisms $(\mathrm{OR}=0.58$; $\mathrm{P}<0.005)$, but not due to Candida species $(\mathrm{OR}=0.56 ; \mathrm{P}=0.97)$ or Gram-positive organisms $(\mathrm{OR}=0.56 ; \mathrm{P}=0.20)$.

Despite highlighting the importance of $\mathrm{MBL}$, a genotyping analysis carried out on 127 neonates failed to show any association between MBL2 genetic polymorphism and neonatal sepsis. ${ }^{23}$

Consistent with the lack of association between MBL levels and infection by Candida sp observed in the study by Auriti et al., another study on a small cohort of 30 septic neonates and 30 healthy premature neonates did not find any association between MBL2 gene polymorphism and nosocomial invasive fungal infection. ${ }^{21}$ Negative results were also found by Koroglu et al..$^{24}$ on 99 premature neonates, in which sepsis was defined by microbiological identification of pathogens in blood cultures. However, when clinical sepsis was the outcome, the frequency of sepsis was higher in the group of infants with MBL gene polymorphism than among infants with wildtype MBL genotype (61.2 versus $31.7 \%$, respectively, $\mathrm{P}=0.008$ ).

Thus, there is so far no evidence that MBL2 gene polymorphism is associated with neonatal sepsis. ${ }^{24}$ One important issue raised by Korogulu et al. is the definition of sepsis. Although sepsis definition based on microbiological identification provides greater certainty for diagnosing sepsis, the low sensitivity of blood cultures and high prevalence of antibiotic usage among neonatal intensive care unit patients can lead to difficulties in microbiological identification. Thus, since finding a positive blood culture is a requirement for sepsis definition, septic patients will certainly be found to be positive. On the other hand, many patients with negative blood cultures and who are considered to be nonseptic may present criteria for clinical sepsis, which may introduce bias into the analysis. Future studies should therefore conduct analyses for both clinical sepsis and proven sepsis. 


\section{IL-1 ra gene polymorphism}

IL-1 receptor antagonist (IL-1ra) is a naturally occurring competitive inhibitor of the proinflammatory cytokine IL-1. Several studies have shown that carrier status for allele 2 of the IL-1ra (IL-1raA2) SNP is associated with greater production of IL-1ra and IL-1 $\beta$ in vivo and in vitro. ${ }^{47-49}$ The single study identified in our search ${ }^{39}$ was carried out on 95 premature neonates (24-35 weeks of gestational age) and, despite confirming that IL-1 ra gene polymorphism had an impact on preterm delivery, it failed to document any impact on early-onset sepsis. The strong points of this study included: a) ethnicity clearly defined; b) gestational age carefully determined; c) a small difference in gestational age (29-32 weeks) between preterm and healthy infants, but reflected in clear differences in birth weight; d) good clinical and microbiological definition of sepsis; and e) incorporation of extra data from adults in an unrelated German study.

\section{Selectin polymorphism}

Only one study addressing selectin polymorphism was retrieved. It included 125 low birth weight infants and 156 healthy term neonates and did not show any association between selectin gene polymorphism and neonatal sepsis, although L-selectin was shown to have an impact in relation to preterm birth. ${ }^{32}$

\section{Angiotensin-converting enzyme} insertion/deletion polymorphism

The renin-angiotensin system plays a complex role in the pathophysiology of sepsis. The angiotensin-converting enzyme (ACE) leads to production of angiotensin II, which is a potent vasoconstrictor and stimulates aldosterone secretion, thereby leading to retention of water and salt. More recently, some evidence of the expression of ACE by macrophages and T lymphocytes, as well as the finding that ACE is also upregulated in the inflammatory response,,$^{50}$ have drawn attention to the inflammatory role of ACE.

Our search retrieved two studies addressing neonatal sepsis and angiotensin-converting enzyme insertion/deletion polymorphism. The first of these included 295 mechanically ventilated VLBW infants and did not show any association between angiotensin-converting enzyme (ACE) insertion/deletion (I/D) polymorphism and neonatal sepsis. ${ }^{36}$ Spiegler et al. confirmed previous observations on the lack of impact of polymorphisms in the renin-angiotensin system, in a large cohort of 1209 VLBW infants. ${ }^{25}$

\section{Polymorphisms associated with glucocorticoid sensitivity}

A single study addressing the association between neonatal sepsis and genetic polymorphisms that affect sensitivity to glucocorticoids (BclI, N363S and ER22/23Ek gene polymorphism) was identified. This study was carried out among 125 premature neonates (28-35 weeks) and did not show any association between these three gene polymorphisms and neonatal sepsis. ${ }^{27}$

\section{Polymorphisms affecting genes of hemostatic factors}

A German multicenter study prospectively evaluated the impact of SNP in relation to genes that code for hemostatic factors (Leiden Factor V; prothrombin G20210A; Factor VII -323 del/ins; and Factor XIII Val34Leu) in 586 very low birth weight newborn children. This analysis was complemented by a retrospective study on a second, comparable group of 595 newborn children. ${ }^{33}$ Carriers of the Val34Leu substitution in Factor XIII presented a higher rate of sepsis and longer hospitalization, in comparison with non-carriers. On the other hand, 323del/ins polymorphism of the Factor VII gene behaved as a potential protective factor against bronchopulmonary dysplasia.

\section{Alternative approaches to the impact of SNP on neonatal sepsis}

In a retrospective case-control study on 535 preterm infants, a total of 49 distinct SNPs affecting 19 separate candidate loci, including genes coding for inflammatory cytokines (IL-6, IL-10, IL-1 $\beta$ and TNF), cytokine receptors (IL-1RN), toll-like receptors (TLR2, TLR4 and TLR5) and endotoxin-binding proteins (CD14) were genotyped. ${ }^{22}$ The subjects were stratified into three groups (sepsis, suspected sepsis and controls) and genotypes were correlated through a transmission disequilibrium test. The authors of this study report that birth weight, gestational age, time elapsed from membrane rupture and presence of clinical chorioamnionitis were strongly associated with sepsis. SNPs in the genes for TLR2 (rs3804099), TLR5 (rs5744105), IL-10 (rs1800896), and PLA2G2A (rs1891320) were associated with sepsis. Allelic variants in PLA2G2A and TLR2 were associated with Gram-positive infection, while IL-10 was associated with Gram-negative infection. The authors concluded that the allelic variants PLA2G2A, TLR2, TLR5 and IL-10 could influence the risk of sepsis among preterm infants. The main limitation of this study lies in its approach, which differs in important ways from that taken in most other studies reviewed above. Hence, while its results are interesting and the approach may hold some promise, the lack of other studies using the same methodology, and the difficulty of reconciling the data with those obtained through the classical approach should emphasize the need for caution in transposing the conclusions to the clinical setting before confirmatory evidence has been obtained.

\section{DISCUSSION}

Any attempt to screen newborns at intensive care units for a given polymorphism because of associations with sepsis relies on 
a number of assumptions: a) that the polymorphisms are associated with sepsis and its outcomes in such a way that makes genotyping an important part of the decision-making process as to whether aggressive antimicrobial therapy should be instituted; b) that this association is not contingent on ethnicity, complex haplotype definitions or the nature of the pathogens involved; and c) that the cost and labor involved in obtaining this genetic information are justified by the benefits expected.

Contrary to the original expectations of many investigators, ${ }^{40,51}$ a decade of efforts by many groups ${ }^{18,52,53}$ to define one or more gene polymorphisms that are sufficiently predictive of susceptibility to sepsis and outcomes to warrant routine use in the neonatal intensive care unit has met with partial success at best. ${ }^{9,45}$ A large proportion of the studies describe negative results (see Results), even in the case of genes for which an impact on sepsis has been consistently reported among adults and older children. ${ }^{9,36}$ Although some studies have reported significant associations between neonatal sepsis and gene polymorphisms, these results have been inconsistent with those from other groups at different times and/or with different populations of neonates (see Results). Most often, strong associations seen in initial studies on small or medium-sized cohorts were not confirmed by studies with much larger groups of patients (comparing ${ }^{51,54}$ with $^{9}$ for TNF- $\alpha$; and ${ }^{40}$ with $^{35}$ for IL-6). There have been no instances in which a large cohort study was the first to identify a major effect on susceptibility to sepsis from any of the candidate genes, although strong effects on predisposing conditions such as premature birth ${ }^{39}$ could be identified through this approach.

Importantly, this stalemate is not dependent on the exact methodology used. For example, one study ${ }^{22}$ used a family-based approach (transmission disequilibrium test) to identify multiple candidate genes associated with neonatal sepsis in a relatively large cohort of infants, and was able to detect moderate to borderline associations with a number of genes (PLA2, TLR subtypes and IL-10). Additional strategies used the definition of septic "phenotypes" based on multiple parameters to improve sensitivity, taking care to correct for the effect of multiple comparisons. None of the most frequently studied polymorphisms in other studies (TNF or IL-6) made it into the list of promising candidates, although PLA2, TLR and IL-10 all fall within the category of immune and inflammatory genes. It is unclear, however, whether a strategy that was developed to explore genotype/phenotype relationships is appropriate for sepsis, which cannot rigorously be considered to be a "phenotype", since it is a rapidly evolving clinical condition, entirely dependent on infectious exposure that can neither be controlled, nor ruled out.

One important aspect of these studies involves the ethnic diversity of the populations examined. In at least one well-controlled study, ${ }^{34}$ ethnicity played a major role in modifying associations between polymorphisms in immunologically relevant genes (IL-6 and CD14) and sepsis-related outcomes. Ethnicity is an issue in other studies conducted in Israel, ${ }^{39}$ the $\mathrm{USA}^{37}$ and Europe. ${ }^{3,25}$ In the latter, this issue is reflected through recent immigration from African and the Middle East ${ }^{25}$ or comparison between widely separated Caucasian populations. ${ }^{3}$ Interpretations on genotyping data are likely to be affected by the ethnic makeup of the population of interest, and this represents a limiting factor for applying this approach to infants worldwide.

Another major issue is the complexity of the polymorphisms involved, which may be quite variable, from single nucleotide polymorphisms in the case of TNF-alpha ${ }^{8}$ to complex insertion and deletion events in the case of ACE. ${ }^{36}$ The complexity is highest in the case of $\mathrm{MBL},{ }^{34}$ since the known mutations often prevent the polymerization that is required for generating a functional protein. Furthermore, such mutations are in strong linkage disequilibrium, and therefore determination of their frequencies is not a simple matter, but involves screening for the existing haplotypes, which do not correspond to all the theoretical possibilities.

This issue further complicates the already complex problem of the functional impact of polymorphisms. The entire rationale behind determining genotypes and allele frequencies depends on a significant connection between genome and function, in addition to the undisputable fact that possession of a functioning gene is necessary for production of a functional protein. In a very few cases, this connection is wellestablished. For instance, demonstration that possession of a given allele in the TNF-alpha system results in significantly reduced transcription rates and decreased protein release was achieved in a non-physiological ex vivo assay. ${ }^{51}$ While it is possible that this reflects physiological potential in the context of sepsis, the latter is much more difficult to ascertain. Other related problems concern the relative impact of single polymorphisms in the TNF region of the MHC on both TNF- $\alpha$ and TNF- $\beta ;^{31}$ and the interrelated effects of polymorphisms in IL-1RA on production of IL-1RA and of IL- $1 \beta .{ }^{39}$

One especially entangled situation concerns MBL. ${ }^{24,29}$ This protein presents a series of polymorphisms that interfere with assembly of functional multimers. As a consequence, individuals who are homozygous for any given mutation, or heterozygous for two distinct mutations, present severe deficiency in this innate microbicidal factor. However, heterozygotes possessing one wildtype allele may produce functional MBL multimers and, since exposure to pathogens stimulates MBL production, deficiency may be difficult to demonstrate. Here, more than anywhere else, the dissociation between genotype and its phenotypic effects is a major issue. Indeed, the clinically relevant issue is not which 
alleles an infant possesses, but how much functional MBL is produced. The discrepancies in the results between studies carried out in ethnically diverse populations ${ }^{24,29,30}$ may be difficult to reconcile without systematic evaluation of the circulating MBL levels. However, there is a good side to this, because measurement of MBL may eventually prove to be a better predictor of sepsis than genotyping and, as a corollary, MBL replacement therapy should be helpful in individuals lacking it. One important issue that cannot be settled at present is whether MBL administration to infants who are utterly lacking in functional multimers might induce antibodies to the exogenous protein.

\section{CONCLUSION}

Genotyping of polymorphisms in the context of neonatal sepsis should be focused on a few markers, in order to reduce labor and costs, and to maximize speed, which is essential in the intensive care setting. While target polymorphisms should be strongly associated with the outcome, in most or all susceptible neonates, the extant literature shows that critical reevaluation of this approach is necessary, since many genes have an impact on sepsis, but none of them meets these requirements. Most importantly, genotyping more than a few of them would be impractical, since their relevance to the decision-making process is difficult to determine. We suggest, instead, that once candidate polymorphisms have been identified in epidemiological studies, their functional relevance should be established, before recommendations for their clinical routine use as genotypic markers are made.

\section{REFERENCES}

1. Goldstein B, Giroir B, Randolph A, International Consensus Conference on Pediatric Sepsis. International pediatric sepsis consensus conference: definitions for sepsis and organ dysfunction in pediatrics. Pediatr Crit Care Med. 2005;6(1):2-8.

2. Lawn JE, Cousens S, Zupan J; Lancet Neonatal Survival Steering Team. 4 million neonatal deaths: when? where? why? Lancet. 2005;365(9462):891-900.

3. Thaver D, Zaidi AK. Burden of neonatal infections in developing countries: a review of evidence from community-based studies. Pediatr Infect Dis J. 2009;28 (1 Suppl):S3-9.

4. Stoll BJ, Gordon T, Korones SB, et al. Early-onset sepsis in very low birth weight neonates: a report from the National Institute of Child Health and Human Development Neonatal Research Network. J Pediatr. 1996;129(1):72-80.

5. Donowitz LG. Nosocomial infection in neonatal intensive care units. Am J Infect Control. 1989;17(5):250-7.

6. Vermillion ST, Soper DE, Chasedunn-Roark J. Neonatal sepsis after betamethasone administration to patients with preterm premature rupture of membranes. Am J Obstet Gynecol. 1999;181(2):320-7.
7. Beck-Sague CM, Azimi P, Fonseca SN, et al. Bloodstream infections in neonatal intensive care unit patients: results of a multicenter study. Pediatr Infect Dis J. 1994;13(12):1110-6.

8. Greenough A. Neonatal infections. Curr Opin Pediatr. 1996;8(1):6-10.

9. Härtel $C$, Hemmelmann $C$, Faust $K$, et al. Tumor necrosis factor- $\alpha$ promoter -308 G/A polymorphism and susceptibility to sepsis in very-low-birth-weight infants. Crit Care Med. 2011;39(5):1190-5.

10. Schrag SJ, Stoll BJ. Early-onset neonatal sepsis in the era of widespread intrapartum chemoprophylaxis. Pediatr Infect Dis J. 2006;25(10):939-40.

11. Nagata E, Brito AS, Matsuo T. Nosocomial infections in a neonatal intensive care unit: incidence and risk factors. Am J Infect Control. 2002;30(1):26-31.

12. Darmstadt GL, Nawshad Uddin Ahmed AS, Saha SK, et al. Infection control practices reduce nosocomial infections and mortality in preterm infants in Bangladesh. J Perinatol. 2005;25(5):331-5.

13. Kramer MS, Demissie K, Yang H, et al. The contribution of mild and moderate preterm birth to infant mortality. Fetal and Infant Health Study Group of the Canadian Perinatal Surveillance System. JAMA. 2000;284(7):843-9.

14. Levy MM, Fink MP, Marshall JC, et al. 2001 SCCM/ESICM/ACCP/ ATS/SIS International Sepsis Definitions Conference. Crit Care Med. 2003;31(4):1250-6.

15. Levy O, Martin S, Eichenwald E, et al. Impaired innate immunity in the newborn: newborn neutrophils are deficient in bactericidal/ permeability-increasing protein. Pediatrics. 1999;104(6):1327-33.

16. Gerdes JS. Clinicopathologic approach to the diagnosis of neonatal sepsis. Clin Perinatol. 1991;18(2):361-81.

17. Ng PC. Diagnostic markers of infection in neonates. Arch Dis Child Fetal Neonatal Ed. 2004;89(3):F229-35.

18. Härtel C, Schultz C, Herting E, Göpel W. Genetic association studies in VLBW infants exemplifying susceptibility to sepsis--recent findings and implications for future research. Acta Paediatr. 2007:96(2):158-65.

19. Bogardus ST Jr., Concato J, Feinstein AR. Clinical epidemiological quality in molecular genetic research: the need for methodological standards. JAMA. 1999;281(20):1919-26.

20. Peters DL, Barber RC, Flood EM, Garner HR, O'Keefe GE. Methodologic quality and genotyping reproducibility in studies of tumor necrosis factor -308 G-->A single nucleotide polymorphism and bacterial sepsis: implications for studies of complex traits. Crit Care Med. 2003;31(6):1691-6.

21. Aydemir C, Onay H, Oguz SS, et al. Mannose-binding lectin codon 54 gene polymorphism in relation to risk of nosocomial invasive fungal infection in preterm neonates in the neonatal intensive care unit. J Matern Fetal Neonatal Med. 2011;24(9):1124-7.

22. Abu-Maziad A, Schaa K, Bell EF, et al. Role of polymorphic variants as genetic modulators of infection in neonatal sepsis. Pediatr Res. 2010;68(4):323-9. 
23. Auriti $C$, Prencipe $G$, Inglese $R$, et al. Role of mannose-binding lectin in nosocomial sepsis in critically ill neonates. Hum Immunol. 2010;71(11):1084-8.

24. Koroglu OA, Onay H, Erdemir G, et al. Mannose-binding lectin gene polymorphism and early neonatal outcome in preterm infants. Neonatology. 2010;98(4):305-12.

25. Spiegler J, Gilhaus A, Konig IR, et al. Polymorphisms in the ReninAngiotensin system and outcome of very-low-birthweight infants. Neonatology. 2010;97(1):10-4.

26. Abdel-Hady H, El-Naggar M, El-Nady G, Badr R, El-Daker M. Genetic polymorphisms of IL-6-174 and IL-10-1082 in full term neonates with late onset blood stream infections. Journal of Pediatric Infectious Diseases. 2009;4:357-65. Avaliable from: http://www.deepdyve.com/ Ip/ios-press/genetic-polymorphisms-of-il-6-174-and-il-10-1082-infull-term-neonates-LXPc8Ep6X5. Accessed in 2013 (May 3).

27. Bertalan R, Patocs A, Vasarhelyi B, et al. Association between birth weight in preterm neonates and the Bcll polymorphism of the glucocorticoid receptor gene. J Steroid Biochem Mol Biol. 2008;111(1-2):91-4.

28. Reiman EM, Chen K, Caselli RJ, et al. Cholesterol-related genetic risk scores are associated with hypometabolism in Alzheimer's-affected brain regions. Neuroimage. 2008;40(3):1214-21.

29. Dzwonek AB, Neth OW, Thiébaut $R$, et al. The role of mannose-binding lectin in susceptibility to infection in preterm neonates. Pediatr Res. 2008;63(6):680-5.

30. van der Zwet WC, Catsburg A, van Elburg RM, Savelkoul PH, Vandenbroucke-Grauls CM. Mannose-binding lectin (MBL) genotype in relation to risk of nosocomial infection in pre-term neonates in the neonatal intensive care unit. Clin Microbiol Infect. 2008;14(2):130-5.

31. Schueller AC, Heep A, Kattner $E$, et al. Prevalence of two tumor necrosis factor gene polymorphisms in premature infants with early onset sepsis. Biol Neonate. 2006;90(4):229-32.

32. Derzbach L, Bokodi G, Treszl A, et al. Selectin polymorphisms and perinatal morbidity in low-birthweight infants. Acta Paediatr. 2006;95(10):1213-7.

33. Härtel C, König I, Köster S, et al. Genetic polymorphisms of hemostasis genes and primary outcome of very low birth weight infants. Pediatrics. 2006;118(2):683-9.

34. Baier RJ, Loggins J, Yanamandra K. IL-10, IL-6 and CD14 polymorphisms and sepsis outcome in ventilated very low birth weight infants. BMC Med. 2006;4:10.

35. Göpel W, Härtel C, Ahrens P, et al. Interleukin-6-174-genotype, sepsis and cerebral injury in very low birth weight infants. Genes Immun. 2006;7(1):65-8.

36. John Baier R, Loggins J, Yanamandra K. Angiotensin converting enzyme insertion/deletion polymorphism does not alter sepsis outcome in ventilated very low birth weight infants. J Perinatol. 2005;25(3):205-9
37. Hedberg CL, Adcock K, Martin J, et al. Tumor necrosis factor alpha -- 308 polymorphism associated with increased sepsis mortality in ventilated very low birth weight infants. Pediatr Infect Dis J. 2004;23(5):424-8.

38. Ahrens $P$, Kattner $E$, Köhler $B$, et al. Mutations of genes involved in the innate immune system as predictors of sepsis in very low birth weight infants. Pediatr Res. 2004;55(4):652-6.

39. Bessler H, Osovsky M, Sirota L. Association between IL-1ra gene polymorphism and premature delivery. Biol Neonate. 2004;85(3):179-83.

40. Harding D, Dhamrait S, Millar A, et al. Is interleukin-6 -174 genotype associated with the development of septicemia in preterm infants? Pediatrics. 2003;112(4):800-3.

41. Treszl A, Kocsis I, Szathmári M, et al. Genetic variants of TNF-[FC12] a, IL-1 beta, IL-4 receptor [FC12]a-chain, IL-6 and IL-10 genes are not risk factors for sepsis in low-birth-weight infants. Biol Neonate. 2003;83(4):241-5.

42. Downs SH, Black N. The feasibility of creating a checklist for the assessment of the methodological quality both of randomised and non-randomised studies of health care interventions. J Epidemiol Community Health. 1998;52(6):377-84.

43. Clark MF, Baudouin SV. A systematic review of the quality of genetic association studies in human sepsis. Intensive Care Med. 2006;32(11):1706-12.

44. Teuffel O, Ethier MC, Beyene J, Sung L. Association between tumor necrosis factor-alpha promoter -308 A/G polymorphism and susceptibility to sepsis and sepsis mortality: a systematic review and meta-analysis. Crit Care Med. 2010;38(1):276-82.

45. Chauhan M, McGuire W. Interleukin-6 (-174C) polymorphism and the risk of sepsis in very low birth weight infants: meta-analysis. Arch Dis Child Fetal Neonatal Ed. 2008;93(6):F427-9.

46. Dommett RM, Klein N, Turner MW. Mannose-binding lectin in innate immunity: past, present and future. Tissue Antigens. 2006;68(3): 193-209.

47. Danis VA, Millington M, Hyland VJ, Grennan D. Cytokine production by normal human monocytes: inter-subject variation and relationship to an IL-1 receptor antagonist (IL-1Ra) gene polymorphism. Clin Exp Immunol. 1995;99(2):303-10.

48. Santtila S, Savinainen K, Hurme M. Presence of the IL-1RA allele 2 $\left(\mathrm{IL}-1 \mathrm{RN}{ }^{*} 2\right)$ is associated with enhanced IL-1 beta production in vitro. Scand J Immunol. 1998;47(3):195-8.

49. Hurme M, Santtila S. IL-1 receptor antagonist (IL-1Ra) plasma levels are co-ordinately regulated by both IL-1Ra and IL-1 beta genes. Eur J Immunol. 1998;28(8):2598-602.

50. Phillips Ml, Kagiyama S. Angiotensin II as a pro-inflammatory mediator. Curr Opin Investig Drugs. 2002;3(4):569-77.

51. Weitkamp JH, Stüber F, Bartmann P. Pilot study assessing TNF gene polymorphism as a prognostic marker for disease progression in neonates with sepsis. Infection. 2000;28(2):92-6. 
52. Del Vecchio A, Laforgia N, Capasso M, Iolascon A, Latini G. The role of molecular genetics in the pathogenesis and diagnosis of neonatal sepsis. Clin Perinatol. 2004;31(1):53-67.

53. Harding D. Impact of common genetic variation on neonatal disease and outcome. Arch Dis Child Fetal Neonatal Ed. 2007;92(5):F408-13.

54. Sipahi T, Pocan H, Akar N. Effect of various genetic polymorphisms on the incidence and outcome of severe sepsis. Clin Appl Thromb Hemost. 2006;12(1):47-54.

Sources of funding: None

Conflict of interest: None

Date of first submission: May 14, 2012

Last received: May 24, 2013

Accepted: May 28, 2013

\section{Address for correspondence:}

Maria Ignez Capella Gaspar Elsas

Av. Rui Barbosa, 716

Laboratório de Fisiopatologia Humana

Flamengo — Rio de Janeiro (RJ) — Brasil

CEP 22250-020

E-mail: elsas@iff.fiocruz.br 